\title{
Russian Foreign Trade under a New Wave of Political Pressure: A Glance from the Inside
}

\author{
Andrey Mikhailitchenko, California State University, Sacramento, USA \\ Sanjay Varshney, California State University, Sacramento, USA
}

\section{Introduction}

It has been a little over two years since a new era in Russia's foreign policy dawned (its annexation of Crimea, suspension from G8, and first round of Western sanctions) in February 2014. The changes and ramifications that followed in Russia, both political and economic, are both extremely drastic and fundamental. The real GDP has plunged, the currency has been significantly devalued, inflation has spiked, and the economy has continued to contract at a rapid rate finally regressing into a recession in 2015 (Figure 1).

\section{Foreign Trade Changes}

Provided below is an overview of the Russian small business climate based on in-depth interviews with owners and managers of a pool of Russian companies working in the Moscow region in the textiles sector and involved in foreign trade activities. The interview results suggest that the most recent foreign trade changes that have the strongest impact on small businesses can be grouped into three major categories: (1) administrative regulations and practices, (2) "grey" customs market development, (3) political restrictions on foreign trade.

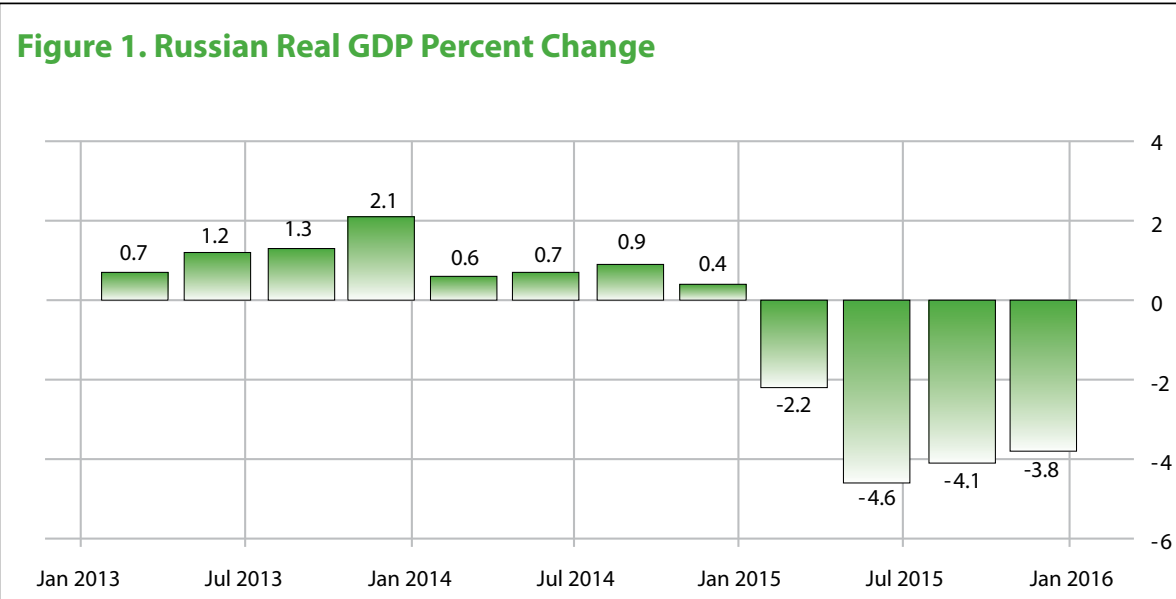

Source: Trading Economics (2015)

\section{New Customs Regulations and Enforcement Practices}

The Russian government's regulation of its foreign trade is limited by tariff commitments and other international obligations that the country has to follow as a member of the World Trade Organization (WTO). However, during the period between the middle of 2014 and the beginning of 2016, a set of new policies de facto revising the existing import tariffs was implemented as a result of newly imposed internal customs rules and practices. While formally not violating any international import tax agreements, these customs rules and practices are creating additional barriers for imports.
While Russian international relations, foreign policy, geo-political developments, and mainstream macroeconomic trends (oil price decline, inflation growth, economic crisis) are quite visible to foreign investors and observers, the changes in government regulations of the Russian economy (both official and covert) as well as their influence on the small business sector are often overlooked or not obvious. These changes are even more pivotal and impactful than those that occur at the macro level. It is noteworthy that it is the microeconomic trends (in contrast to macroeconomic and political) that determine the investment climate in a country and its attractiveness for entrepreneurial activity. The small business sector is the lifeblood and backbone of any major economy, often responsible for creating many more net new jobs on the margin, and countries that have thriving small businesses tend to be more economically successful.
The most impactful measure that directly increases the amount of duties to be paid by importers, thereby increasing the costs of imported goods, is the so-called "customs risk management system." This system exists in the internal rules and regulations (letters, orders, and instructions) of the Federal Customs Service (FCS) that are communicated to the local customs offices responsible for clearance of customs declarations. These regulations are critical when the imported goods are subject to payments of duties and import VAT calculated as a percentage of the declared value of the imported goods (product value and the freight and insurance costs). In these cases, Customs has the option to agree with the value of the goods declared by the importer and release the merchandise with payment of regular duties, or disagree and initiate the procedure of declared value investigation.

Before June 2015, the system of internal customs regulations generally allowed normal customs clearing procedures based on the actual 
contract prices of the goods. For example, knitted fabrics (Harmonized System (HS) code 60019200) were allowed to be normally cleared if the declared cost at the Russian border did not go below $\$ 2.55$ per kg, which generally corresponds to the international market prices for this type of goods. However, on June 26, 2015, in an internal customs order $(11 / 10000 / 25062015 / 03202$, version 10) the "risk value" for this item was increased up to $\$ 6.00 / \mathrm{kg}$ for goods imported from China, $\$ 8.50 / \mathrm{kg}$ for most other countries, and $\$ 10$ for the group of countries that includes USA, Canada, Japan, and most of the EU members. Local customs offices were informed that if the declared amount for the goods in this HS code is less than levels mentioned above, the criterion of rejection and further investigation should be stated as "submitted customs documents contain not sufficient or contradictive information or information causing suspicion in its truthfulness" (Russia Federal Customs Service, 2015).

As part of further investigation, the declarant has to provide a long list of supplementary documents such as price list of the trade partner, foreign partner's export customs declaration, accounting documents, etc. The barrier is high and often impossible to overcome given the amount of accompanying conditions, such as verification by the Chamber of Commerce of the foreign country, legal notarization, and presence of information that may constitute the commercial secret of a supplier (e.g., technological breakdown of the product costs that is also required by the customs).

Before these documents are provided, the goods can be released only under the condition of full pre-payment of all duties and taxes based on the assumption of the declared value stipulated in the customs order. For instance, if the actual value of a $40^{\prime} \mathrm{HQ}$ container is around $\$ 30 \mathrm{~K}$, the amount of duties to be paid is $7 \%$ and VAT of $18 \%$, resulting in a total amount around \$7.8K. However, based on the "customs risks" order, the importer cannot get the goods released without paying $\$ 15 \mathrm{~K}$ to $\$ 19 \mathrm{~K}$, depending on the judgment of a local customs officer.

The procedure of reimbursement of the overpaid duties and taxes takes several months and is multi-level, i.e., after the documents are considered in the local customs office, the application for overpaid duties return should be resubmitted to the regional customs office and again considered there. During this process the importer can still be subject to additional document requests and verification requirements and can be subjected to the procedure of "customs cost correction" without any return of payments made. Formally, the importers can try to protect themselves through a lawsuit, but given the time, resources, and high degree of courts' dependence upon administrative authorities, the questionable outcome of such a trial makes most of the importers not consider this option at all.

As a result, in 2015 customs control departments made 4,782 customs investigations among which 3,972 resulted in fines and penalties. The total amount of additionally charged and collected duties, penalties, and fines during that period was 12.7 billion rubles (187 million USD), 24.5\% higher than in 2014 (Russia Federal Customs Service, 2016).

\section{"Grey" Customs Clearing System}

Additionally, a parallel "grey" system of customs clearing exists, resulting in a strong impulse for developing and getting new clients after June 2015, as a result of the new "risks level" imposed by FCS. Definite firms (apparently affiliated with high-level customs officers and other representatives of administrative power) are offering customs clearing without providing legal customs declaration, but with substantially lower amount of expenses paid than official import duties and taxes. The 40'HQ container mentioned above could be cleared through the "grey" customs market for $\$ 10-12 \mathrm{~K}$. That is still higher than actual legal duties, but lower than what would be paid if the importer went through customs clearing without this intermediary. As a result, the payment is actually split: a certain amount goes to the budget, while part of it is channeled elsewhere as unofficial cash. Given the choice between the expensive "grey" and super-expensive "white" customs clearing, most of importers prefer to go with the "grey" option.

Based on the opinion of most interviewees, the system of "customs risks management" as it has been enforced since summer 2015 is aimed at two major goals: (1) to attempt to fix budget holes by increasing the burden on importers, primarily in the small business sector and (2) to create another channel of unofficial cash inflow for administrators on different levels. Combined with the crisis conditions in the Russian economy (fall of Russian ruble, decline in living standards, and buying capacity, etc.) these new regulations have forced most importers either to temporarily stop their foreign trade operations or to completely withdraw from the business. Those who are still continuing their operations do not have any reasonable choice other than to seek "grey" intermediaries' help.

\section{Additional Political Restrictions}

Another new area of hidden customs regulations that has a direct impact on Russian small business is political restrictions. In addition to limitations on the import of agricultural products, raw materials, and food products from EU countries that have existed since summer 2014, a new wave of embargoes, both official and unofficial, was imposed in November 2015 on goods imported from Turkey after the incident with the shooting down of a Russian bomber aircraft near the Syria-Turkey border on November 24, 2015. The list of banned import items mostly includes different types of agricultural products. Additionally, except for the direct embargo, other different internal customs regulations have been introduced and implemented as well.

The instruction 55/10000/24112015/60113, sent from FCS to local customs offices, contains the requirement to make all products either originated or shipped from Turkey, or transported by Turkish carriers, the subject of the special procedures. These procedures include 100\% inspection of the merchandise with full unloading of the containers, weighing of the items, taking samples, and their subsequent verification regarding declared customs value. As a result, not only the agricultural products that were listed in the official government ruling (Russian 
Federation Government, 2015) but also all others either produced or shipped through Turkey have become the subject of newly constructed customs barriers (Platonova, Romanova, \& Kalachihina, 2015).

One example is textiles, which are roughly $18 \%$ of total imports from Turkey to Russia. Most of the Russian companies that purchase textile products (fabrics, yarn, accessories, etc.) from Turkey are small businesses. One of the interviewees, an owner of a textile trading company importing terry fabrics from Turkey, said: "Our containers got stuck in the port Novorossiysk. Every day that they are held by customs brings us huge losses, both direct and indirect. And there is no way to expect that they will be released in the foreseeable future. We paid for this shipment way before the accident with the Russian plane, so it is not our Turkish suppliers but we, Russian businesses, who are suffering. Why and what are we punished for?"

\section{New Corruption Opportuni- ties}

The political restrictions on imports from Turkey immediately resulted in expanded offerings by "grey" and "black" customs clearing markets. The new ways

to work around the limitations, like in the case of sanctions against agricultural products from EU countries, are mostly related to transit through countries belonging to the Eurasian Economic Union (EEU) such as Belarus and Kazakhstan. The corruption schemes offered on the market include delivering the merchandise to one of the EEU countries, unloading the container, and then transporting the goods by truck as originated in some other country.

In order to prevent the possibility of re-export under the practice, the FCS established Mobile Inspection Complexes, tasked with patrolling borders with Kazakhstan and Belarus and preventing any illegal transit. However, companies advertising their transit services undertake obligations to resolve problems with customs officials on these complexes for a fee. Importing from Turkey as a result became more expensive (average increase of transit costs by more than $\$ 3 \mathrm{~K}$ per $40^{\prime} \mathrm{HQ}$ container) and susceptible to corruption.

Another opportunity advertised by "grey" freight forwarders through social networks and other channels is transportation to Finland (port Kotka), reloading of the merchandise from container to truck, and transporting to the territory of Russia by parts as loose cargo received from China. Using this scheme adds around \$5K to the cost of container transportation. In general, as it often happens with restrictive regulations in Russia, illegal imports are not prevented, but rather create new corruption opportunities.

\section{Macroeconomic Impact}

Attempts to squeeze more taxes from import and restrictive customs measures were key factors leading to the decline in Russia's international trade, especially imports. According to the data released by the Russia Federal State Statistics Service, external trade turnover in 2015 declined by $34.3 \%$ in comparison to 2014 (from 806.1 to 534.4 billion USD), while imports declined by 37.0\% (from 308.1 to 194.1 billion USD) (Russia Federal State Statistics Service, 2016a). Such a downfall in foreign trade
Figure 2. Russia's Import and Export Dynamics (\% to December 2013)

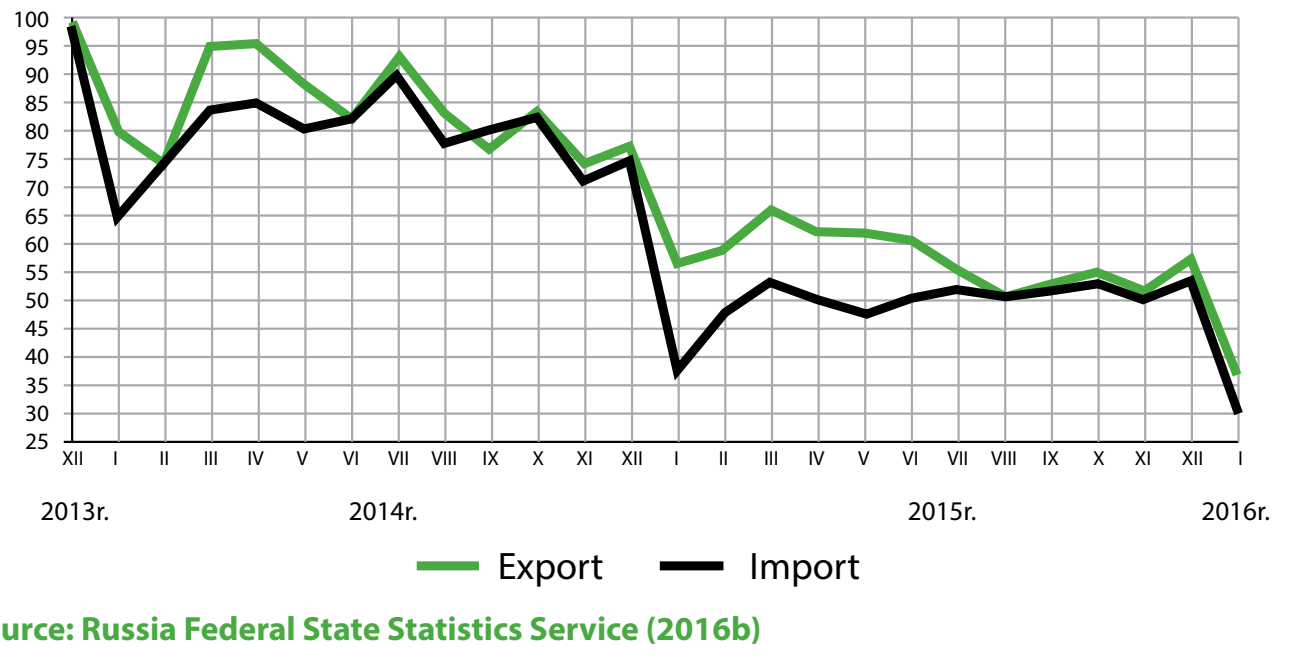

and imports in particular creates the likelihood for further weakening of the Russian ruble, shrinking demand, and overall economic decline.

For potential investors and foreign trade partners, recent measures imply further increased transaction costs of doing international trade business in Russia. Currently, according to the World Bank Investments Strategy Group, the transaction costs for exporting one container of goods from Russia are 2.0 times higher than from the U.S. and 3.2 times higher than from China (Figure 3). With the restrictive measures from recent months, the gaps will definitely widen.

Figure 3. Cost to Import One Container

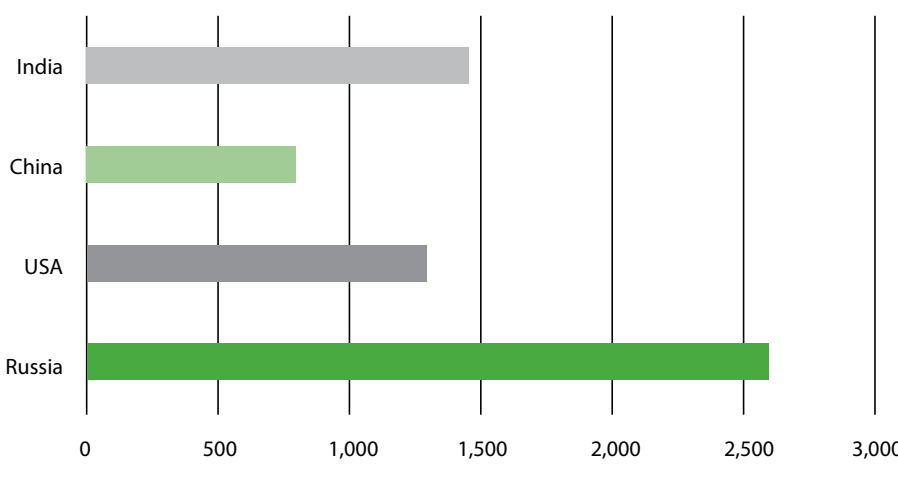

Source: World Bank(2014) 


\section{Institutional Changes}

In terms of wider impact on the Russian political system as a whole, the latest restrictions have definitely contributed to the traditional challenges in the Russian economy: "manual" type of management at all levels of the administrative pyramid, and the minimal rule of law. This point of influence can be characterized as the institutional impact. According to Robinson and Acemoglu (2012), while strong "inclusive" political and economic institutions nurture market competition, property rights, and depth in financial markets, countries with "extractive" institutions, in contrast, do not sustain growth, concentrate political power in the hands of a narrow elite, and extract resources from the rest of society for the benefit of this elite.

The crisis in Russian foreign policy and subsequent sanctions, followed by the economic recession and budget deficit, is one more sign of the lack of "inclusive" institutions in the country. The situation with the new wave of politically driven customs regulations that harms first of all Russia's own small businesses plays in favor of empowering "extractive" institutions in the governance mechanism at all levels and conserves the current hyper-centralized and corrupted political system.

Currently Russia ranks 143 $3^{\text {rd }}$ on the 2015 Index of Economic Freedom with an overall economic freedom score of 52.1, and it is included in the category of Mostly Unfree countries (with scores in the range of 50-60) (Heritage Foundation, 2015). However, the latest events in the Russian economy and government regulations of business, especially in the areas of foreign trade and the small business sector, clearly demonstrate the declining trend, with the strong possibility of further downgrading in this list in the foreseeable future. Overall, the latest economic events provide further evidence of Russia's challenges and show that the transformation has been anything but positive.

\section{Implications for Future Research and Business Practice}

This analysis and results have strong implications for further research, business practices, the state of public policy, and more importantly, changes needed therein. Russia, once a star emerging market (part of BRICS) that was considered a major growing economic power, seems to have lost its luster amid declining consumer and business confidence and corrupt and unstable practices. Much reform is needed on both the economic and political fronts to allow Russia to be once again considered a major player among world economies that has a positive impact on the global landscape. Our analysis and insights will hopefully add to this discussion.

We see at least two key areas of research that are worthy of close attention in the foreseeable future: (1) Russian economic resources in turbulent environments and the current state of its critical sectors and (2) short-term impact and long-term consequences of economic sanctions against Russia and its counter-sanctions on the European and world economies. The dynamics of the changes in Russia as a whole and in its foreign trade in particular have increased drastically during the last two years, and in the worst case scenario, the situation could culmi- nate in an uncontrollable state at some point. Thus, close monitoring of the external and internal economic processes and regular analysis are needed more than ever before to keep the economic environment in Russia and around it understandable and predictable on all stages of the crisis development.

\section{References}

Bryson, J. \& Nelson, E. 2015. Russian Economy on the Long, Slow Road to Recovery. Wells Fargo Securities Economics Group, November 2015

Heritage Foundation. 2015. Index of Economic Freedom. http://www.heritage. org/index/. Accessed November 11, 2015

Platonova, E., Romanova, K., \& Kalachihina, Y. 2015. War against Turkish Tomatoes. Gazeta.ru, November 26: http://www.gazeta.ru/ business/2015/11/25/7915805.shtml. Accessed November 28, 2015.

Robinson, J., \& Acemoglu, D. 2012. Why Nations Fail: The Origins of Power, Prosperity, and Poverty. New York: Crown Business.

Russia Federal Customs Service. 2015. Order No.1071, 06/02/2015. http:// www.alta.ru/tamdoc/15pr1071/. Accessed August 24, 2015.

Russia Federal Customs Service. 2016. Newsletter 01/28. http://www.logistic.ru/news/news.php?num=2016/01/28/13/31269199. Accessed March 31, 2016

Russia Federal State Statistics Service. 2016a. Russian Federation External Trade in January 2016. http://www.gks.ru/bgd/free/b04_03/IssWWW.exe/ Stg/d06/52.htm. Accessed March 31, 2016.

Russia Federal State Statistics Service. 2016b. Russia Import \& Export Dynamics (\% to December 2013). http://www.gks.ru/free_doc/2016/b16_01/ image2048.gif. Accessed March 31, 2016.

Russian Federation Government. 2015. Order No.1296, 11/30/2015. http:// government.ru/media/files/GRARiHdNIWbI10wUg3LyPSAJPIDeTnLX.pdf. Accessed December 10, 2015.

Trading Economics. 2015. Russia Economic Indicators. http://www.tradingeconomics.com/russia/indicators. Accessed March 31, 2016.

World Bank. 2014. World Development Indicators. http://data.worldbank.org/ indicator/IC.IMP.COST.CD/countries/1W-RU-US-CN?display=default. Accessed November 14, 2015.

Andrey Mikhailitchenko (mikhaili@csus.edu) is an Associate Professor of Marketing and Director of the Center for Small Business at California State University, Sacramento. He is also CEO of Russia-based international trading company Continent-Textile Ltd. with more than 20 years of managerial experience in international trade. He authored numerous articles in academic and industrial journals and a textbook used in business institutions in USA, Germany, Japan and other countries.

Sanjay Varshney (varshney@csus.edu) is a Professor of Finance at California State University, Sacramento, and Vice President/Investment Strategy Specialist for California and Nevada at Wells Fargo Private Bank - Wealth Management Group. He recently served as the Vice President for Economic and Regional Partnerships and Dean of the College of Business Administration at Sacramento State for 10 years. 